A N N A LES

UNIVERSITATIS MARIAE CURIE-SKŁODOWSKA

LUBLIN - POLONIA

VOL. LXX

SECTIO F

2015

Narodowa Akademia Nauk Ukrainy

Instytut Ukrainoznawstwa im. I. Krypiakiewicza

OLGA HUL

Przywódcy pospólstwa miasta Lwowa

w czasie wystapień przeciwko radzie miejskiej w latach 1576-1577

The Leaders of the Town Populace During the Civil Protests in Lviv in 1576-1577

\title{
STRESZCZENIE
}

W drugiej połowie lat 70. XVI w. Lwów stał się areną wystąpień społecznych przeciwko władzy rady miejskiej. Główne przyczyny konfliktu tkwiły w sytuacji wewnętrznej miasta i funkcjonowaniu jego gminy. Rajcy nie podjęli rozmów z przedstawicielami opozycji, obrażali ich, a nawet grozili karami. Było to powodem skierowania przez pospólstwo skargi do króla. W trakcie dalszych działań na czoło opozycji mieszczańskiej wysunęło się kilka osób (Jan Zaidlicz, Jakub Soszka, Jan Szulczik, Jan Ganszorn, Jan Niedźwiedź, Jan Orzeszek), którzy reprezentowali ogół mieszczaństwa lwowskiego na sesjach sądowych w grodzie lwowskim oraz na dworze królewskim. Byli ludźmi dość bogatymi, jednak nieposiadającymi władzy w mieście. Głównym powodem ich zaangażowania się $\mathrm{w}$ organizację ruchu mieszczan przeciw władzom było zapewne pragnienie wejścia do grona elity władzy czy też likwidacja barier ją tworzących. Ruch ten znalazł poparcie wśród licznych grup mieszkańców Lwowa.

Słowa kluczowe: Lwów; wystąpienie społeczne; konflikt; pospólstwo; rada miejska; opozycja

W drugiej połowie lat 70. XVI w. Lwów stał się widownią wystąpień społecznych przeciwko władzy rady miejskiej. Główne przyczyny konfliktu tkwiły w sytuacji wewnętrznej miasta i funkcjonowaniu jego gminy. Do najważniejszych źródeł niezadowolenia mieszczan należy zaliczyć problem nadużyć urzędników miejskich i coraz większej zależności życia miasta (we wszystkich jego przejawach) od decyzji rady miejskiej. Wydarzenia te były częścią szerszego zjawiska, 
związanego z ruchem pospólstwa miast królewskich występującego przeciwko dotychczasowemu sposobowi sprawowania władzy w gminach miejskich, jakie obserwujemy w trzecim ćwierćwieczu XVI w. w Koronie'.

Na szerzenie się nastrojów konfliktowych w mieście wpływ miała też ogólna sytuacja w państwie. Bezkrólewie wiązało się ze wzrostem wydatków miasta, głównie na opłacenie ludzi zaangażowanych do jego obrony. Ponadto miasto potrzebowało pieniędzy na wyjazdy delegacji na sejmy koronacyjne ${ }^{2}$. Żeby sfinalizować te potrzeby, rada miejska zarządziła w 1570 r. pobieranie podatku w podwójnej wysokości, tzw. szos „duplo”3. Już w czasie konfliktu przedstawiciele pospólstwa skarżyli się w urzędzie grodzkim na rajców, że samowolnie zwiększali podatki miejskie 4 . Oprócz tego rajcy nie przestrzegali obowiązku składania sprawozdań z wydatków miejskich, zwłaszcza w latach $1562-1569^{5}$. W latach 1573-1576, ze względu na bezkrólewie, a następnie koronację Henryka Walezego i Stefana Batorego, nie były przeprowadzane elekcje władz miejskich, co wywołało niezadowolenie pospólstwa i znalazło odbicie w petycji skierowanej do króla. Wszystkie omówione wyżej przyczyny wraz z obserwowaną coraz silniej tendencją do zamykania się elity władzy doprowadziły do uformowania się opozycji ${ }^{6}$.

Apogeum niezadowolenia miało miejsce w sierpniu 1576 r., kiedy mieszczanie Lwowa zebrali się w ratuszu, aby oprotestować pobieranie szosu w podwójnym wymiarze ${ }^{7}$. Rajcy nie podjęli rozmów z przedstawicielami opozycji, obrażali ich i nawet grozili procesem sądowym oraz karami. Było to powodem skierowania przez pospólstwo skargi do króla, która zapoczątkowała długi spór

${ }^{1}$ Zob. R. Szczygieł, Konflikty społeczne w miastach Królestwa Polskiego w XV i XVI wieku, związane z dostępem do władz miejskich, http://history.org.ua/JournALL/socium/7/4.pdf [dostęp: 10.02.2017], s. 41-42.

${ }^{2} \mathrm{Na}$ początku 1574 r. na sejmie koronacyjnym miasto reprezentowali: rajcy Mikołaj Gelazinus i Jan Zaleski, ławnik Bartłomiej Gazdowski oraz dwie osoby od starszych Ormian. Miasto wydzieliło na wyjazd tej delegacji na koronację 932 fl. 67 gr. Zob. Centralnyj Derżawnyj Istorycznyj Archiw Ukrainy u Lwowi (dalej: CDIAUL), f. 52, op. 2, spr. 712, s. 202.

${ }^{3}$ CDIAUL, f. 9 , op. 1, spr. 335, s. 576-592; CDIAUL, f. 52, op. 2, spr. 770, s. 1-242. Szos za lata 1569-1576 (zwłaszcza szos za 1571 r.) był przeznaczony na wysłanie delegacji do Warszawy w sprawie lustracji; w 1573 r. - na zarządzanie miastem w czasie bezkrólewia; w 1574 r. - na wysłanie posłów na koronację króla; w 1575 r. - na wysłanie posłów na sejm generalny elekcyjny do Warszawy; w 1576 r. - na drugi sejm koronacyjny; w 1576 r. - na sejm koronacyjny króla Stefana i królewny Anny.

${ }^{4}$ CDIAUL, f. 9 , op. 1 , spr. 336, s. 844.

${ }^{5}$ CDIAUL, f. 52, op. 1 , spr. 97, s. 36v.

${ }^{6}$ Dokładniej o przyczynach i przebiegu wydarzeń zob. O. Hul, Konflikt między pospólstwem a wladzami miasta Lwowa w latach 1576-1577. Przebieg wydarzeń i zasięg społeczny, [w:] Emocje w życiu mieszkańców miast na przestrzeni dziejów. Zbiór studiów, red. A. Buczyło, J. Możdżeń, A. Mutrynowska, Toruń 2015, s. 191-203.

${ }^{7}$ CDIAUL, f. 9, op. 1, spr. 336, s. 839-844, 908 (28 sierpnia 1576 r.). 
w gminie miejskiej przy zaangażowaniu dworu króla Stefana Batorego ${ }^{8}$. Niedługo po tym, 8 września 1576 r., koło klasztoru franciszkanów zebrali się przedstawiciele cechów rzemieślniczych, którzy dla dobra swojego i całej gminy wystąpili przeciwko radzie miejskiej i zwoływali pospólstwo, ,aby się schodziło razem"9. $\mathrm{Z}$ otwartym protestem wystąpiło wtedy 72 rzemieślników ${ }^{10}$ : Jakub Daniecki ${ }^{11}$, Szymon Stolnikowski ${ }^{12}$, Jan Bigos ${ }^{13}$, Sebastian Zieliński ${ }^{14}$, Franciszek Jakubowski $^{15}$, Melcher Gajecki ${ }^{16}$, Jan Rzeszowski ${ }^{17}$, Bartłomiej Strach ${ }^{18}$, Jan Kukla ${ }^{19}$, Stanisław Parvus ${ }^{20}$, Marcin Młody Hanel ${ }^{21}$, Jerzy Mildt' ${ }^{22}$, Szczęsny ${ }^{23}$, Wojciech Era-

${ }^{8}$ CDIAUL, f. 52, op. 1, spr. 97, s. 34-34v; Соціальна боротьба в місті Львові в XVI-XVIII cm., зб. док, під ред. Я. Кіся, Львів 1961, s. 36-39.

${ }^{9}$ CDIAUL, f. 9, op. 1, spr. 336, s. 1259.

${ }^{10}$ Ibidem, s. 1260.

${ }^{11}$ Był zięciem rajcy Jana Grynwalta, prawo miejskie przyjął w 1558 r. (Album civium Leopoliensium. Rejestry przyjęć do prawa miejskiego we Lwowie 1388-1783, wyd A. Janeczek, t. 1-2, Poznań - Warszawa 2005, nr 2468).

${ }^{12} \mathrm{~W} 1572$ r. dał list polecający dla kuśnierza Jakuba Dziekanowicza (ibidem, nr 2852).

${ }^{13}$ Był cechmistrzem cechu rzeźnickiego, w latach 1576-1585 niejednokrotnie występował jako poręczyciel przy udzielaniu prawa miejskiego (ibidem, nr 2966, 2972, 2979, 3016, 3072, 3614).

${ }_{14}$ Pochodził z Krakowa, do rejestrów prawa miejskiego został przyjęty w 1558 r. (ibidem, nr 2475).

${ }^{15}$ Pochodził z Kalisza, prawo miejskie we Lwowie uzyskał w 1575 r. (ibidem, nr 2959).

${ }^{16}$ Pochodził z Żydaczowa, prawo miejskie uzyskał w 1576 r., poręczył za niego Jan Ganszorn (ibidem, nr 2971).

${ }^{17}$ Odnotowano wzmianki o trzech osobach z takim imieniem i nazwiskiem - w 1552 r. przyjął prawo miejskie Jan Rzeszowski (ibidem, nr 2292); w 1540 r. do rejestrów został przyjęty Jan Rzeszowski z Przemyśla (ibidem, nr 2008); jeszcze jeden Jan Rzeszowski przedmieszczanin (civium auteurbanorum) w 1568 r. poręczył za Lukasa Borszlińgowicza (ibidem, nr 2724).

${ }^{18}$ Zapisany jako Bartoszek Strach. W 1576 r. posiadał już prawa obywatelskie we Lwowie, w tym roku poręczył za Stanisława Gorczynskiego i Mikołaja z Brzezin (ibidem, nr 2977).

${ }^{19}$ Kuśnierz z Krakowa, przybył do Lwowa w 1573 r. (ibidem, nr 2865).

${ }^{20}$ Zajmował się produkowaniem ksiąg z pergaminu, pochodził ze Lwowa, prawo miejskie przyjął w 1573 r. (ibidem, nr 2882).

${ }^{21}$ Martinus junior - syn Marcina Hanela ze Lwowa, prawo miejskie przyjął w 1570 r. (ibidem, nr 2790); był rzeźnikiem (ibidem, nr 2988, 2990).

${ }^{22} \mathrm{~W}$ dokumencie zapisany jako Jurek Miltz. W 1559 r. posiadał prawa obywatelskie, poręczył za Mikołaja Omelanowicza Rusina (ibidem, nr 2484); w latach 1561-1577 był poręczycielem (ibidem, nr 2546, 2555, 2992).

${ }^{23}$ Zapisany jako Sczesnyszalia. W rejestrach przyjęć do prawa miejskiego są wzmianki o czterech osobach z takim nazwiskiem: Szczęsny - kotlarz z Warszawy, przyjął prawo miejskie w $1545 \mathrm{r}$. (ibidem, nr 2135); Szczęsny contrifusor był poręczycielem w 1548 r. (ibidem, nr 2209); Szczęsny z Halicza przyjął prawo miejskie w 1546 r. (ibidem, nr 2157); Szczęsny - kuśnierz z Piotrkowi, prawo miejskie przyjął w 1542 r. (ibidem, nr 2051). 
zmusowicz $^{24}$, Kasper Kazimleko ${ }^{25}$, Stanisław Długos ${ }^{26}$, Franciszek Matisowicz ${ }^{27}$, Adam bednarz ${ }^{28}$, Andrzej Grygrowicz ${ }^{29}$, Sczęsny Stary komisarz ${ }^{30}$, Jan Duchna złotnik $^{31}$, Paweł Czopowicz ${ }^{32}$, Maciej Chlopowicz ${ }^{33}$, Jurek Wojnarowicz rzeźnik ${ }^{34}$, Wojciech Wójcik ${ }^{35}$, Jakub Ogorzałek ${ }^{36}$, Gregier krawiec ${ }^{37}$, Jan Ganszorn ${ }^{38}$, Marcin Ziarnko stolarz ${ }^{39}$, Baltazar bednarz ${ }^{40}$, Jakub Dziekan (Dziekanowicz) ${ }^{41}$, Tomasz krawiec ${ }^{42}$, Tomasz Soltiszek (Szoltisek) ${ }^{43}$, Tomasz Sixtowicz (Sixt) ${ }^{44}$, Jerzy Turski $^{45}$, Stanisław Mazgaj garncarz ${ }^{46}$, Jan Wolski miecznik ${ }^{47}$, Tomas Birkowski ${ }^{48}$,

${ }^{24}$ Zapisany jako Wojciech Erazmusik. Pochodził ze Lwowa, prawo miejskie przyjął w 1555 r. (ibidem, nr 2381); był szewcem, w 1571 r. wystąpił jako poręczyciel (ibidem, nr 2834).

${ }^{25}$ Pochodził z Krakowa, prawo miejskie przyjął we Lwowie w 1573 r. (ibidem, nr 2885).

${ }^{26}$ Pochodził z Radomia, prawo miejskie przyjął we Lwowie w 1565 r. (ibidem, nr 2642).

${ }^{27}$ Był rzeźnikiem, pochodził ze Lwowa, prawo miejskie przyjął w 1565 r. (ibidem, nr 2654).

${ }^{28}$ Pochodził z Mościsk, prawo miejskie przyjął w 1549 r. (ibidem, nr 2232).

${ }^{29} \mathrm{~W}$ dokumencie podany jako Andrzej Grigrowicz. Kuśnierz, pochodził ze Lwowa, prawo miejskie przyjął w 1575 r. (ibidem, nr 2945).

${ }^{30} \mathrm{Nie}$ posiadamy o nim żadnej informacji. Być może jest to jeden ze Szczęsnych wymienionych w przypisie 23 .

${ }^{31}$ Pochodził ze Lwowa, z rodziny złotników, prawo miejskie przyjął w 1543 r. (Album civium Leopoliensium..., $\mathrm{nr}$ 2091).

${ }^{32}$ Zapisany jako Paweł Czop. Był kuśnierzem, pochodził z Lublina, prawo miejskie przyjął we Lwowie w 1564 r. (ibidem, nr 2624).

${ }^{33}$ Kuśnierz, pochodził ze Lwowa, prawo miejskie przyjął w 1573 r. (ibidem, nr 2875).

${ }^{34}$ Prawdopodobnie syn rajcy Jerzego Wojnara, prawo miejskie przyjął w 1558 r. (ibidem, nr 2469).

${ }^{35}$ Kuśnierz, pochodził z Potoka, prawo miejskie przyjął w 1558 r. (ibidem, nr 2465).

${ }^{36}$ Kuśnierz, pochodził z Zalesic, prawo miejskie przyjął w 1567 r. (ibidem, nr 2719).

${ }^{37}$ W 1540 r. był poręczycielem Jana Przepiórka (ibidem, nr 1998).

${ }^{38}$ Cechmistrz cechu kuśnierzy, prawo miejskie przyjął w 1570 r. (ibidem, nr 2794).

${ }^{39}$ Członek Quadragintawiratu (1579-1580). Zob. M. Kapral, Urzędnicy miasta Lwowa w XIIIXVIII wieku, [w:] Spisy urzędników miejskich z obszaru dawnej Rzeczypospolitej, Ślaska i Pomorza Zachodniego, t. 7: Ziemie Ruskie, z. 1, Lwów - Toruń 2008, nr 1446.

${ }^{40}$ Prawo miejskie przejął w 1548 r. (Album civium Leopoliensium ..., $\mathrm{nr}$ 2194).

${ }^{41}$ Pochodził z Nieprowicz, prawo miejskie przyjął w 1572 r. (ibidem, nr 2852).

${ }^{42}$ Starszy cechowy, w 1578 r. wystąpił jako poręczyciel (ibidem, nr 2997).

${ }^{43}$ Prawo miejskie przyjął w 1545 r. (ibidem, nr 2145).

${ }^{44}$ Starszy cechowy cechu stolarzy, w latach 1573-1598 występował jako poręczyciel (ibidem, nr 2872, 2974, 3297, 3423, 3425).

${ }^{45}$ Starszy cechowy cechu szewskiego, pochodził z Krakowa, prawo miejskie przyjął w $1559 \mathrm{r}$. (ibidem, nr 2477).

${ }^{46}$ Pochodził ze Lwowa, był starszym cechowym cechu garncarzy, prawo miejskie przyjął w 1551 r. (ibidem, nr 2281).

${ }^{47}$ Pochodził ze Slawin, prawo miejskie przyjął w 1556 r. (ibidem, nr 2419).

${ }^{48}$ Kuśnierz, był zięciem Macieja Sochy, prawo miejskie przyjął w 1570 r. (ibidem, nr 2793). 
Wojciech krawiec ${ }^{49}$, Jan Modzeński garbarz ${ }^{50}$, Stanisław szewc ${ }^{51}$, Maciej Bydlowski $^{52}$, Simon Kinost rymarz ${ }^{53}$. O następnych osobach z tego wykazu nie udało się odnaleźć informacji. Byli to: Jan piekarz, Brikszy szewc, Mikołaj Starnigel, Matiszek Kusvicz, Jan Złotnik, Józef Niedziela garncarz, Balcer garncarz, Piotr Kulia garncarz, Kasper Kowal, Vasili kotlarz, Matis Barmina, Jan kowal, Stanisław Witkowicz, Jurga Pluczistiali, Stanisław Wytkowicz, Tomasz rymarz, Jan Szulczik krawiec, Wacław i Bartosz Paterowie, Simon Gryf bednarz, Stanisław Sosna, Wojciech Gaska, Melcher Lezibok rymarz, Jurek Barwicz, Andrzej Lupnar rzeźnik „,zo liczby słucha”, Blażej zamesznik, Adam Kozielnicki, Janus Węgrzyn krawiec, Jan Stamigiel bednarz.

Należy uznać, że wyżej wymienieni uczestniczyli w otwartym wystąpieniu pospólstwa przeciwko rządom rady miejskiej i agitowali mieszczan do podjęcia zdecydowanych działań. Jak wynika z zebranych informacji, byli to przedstawiciele rzemiosła i innych stowarzyszeń zawodowych. Spośród 72 osób udało się ustalić zawód 41. Najwięcej było wśród nich krawców i kuśnierzy (po 6), rzeźników (5), bednarzy (4), szewców i garncarzy (po 3), rymarzy, złotników, stolarzy, kowali (po 2) oraz po jednym reprezentancie kotlarzy, piekarzy, garbarzy, mieczników, zameszników i introligatorów.

W trakcie dalszych działań pospólstwa na czoło opozycji mieszczańskiej wysunęło się kilka osób, które reprezentowały ogół mieszczaństwa lwowskiego na sesjach sądowych w grodzie lwowskim i na dworze królewskim. Dekret malborski tak ich określa: nomine vero communitatis famatis Joannes Zaidlicz, Jacobo Soszka pellione, Joannes Szulczik sartore et Joannes Ganszorn pellione, civibus, necnon Joannes Niedzwiedz cerdone et Joannes Orzeszek suburbanis ${ }^{54}$. Oprócz imion i nazwisk w dekrecie wymienione są również ich zawody. Było wśród nich dwóch kuśnierzy i krawców, garbarz oraz kupiec. Czterech z nich było przedstawicielami bogatych organizacji rzemieślniczych - cechu krawieckiego i kuśnierskiego. Nasuwają się pytania, kim byli ci ludzie, dlaczego właśnie oni kierowali akcją pospólstwa, czy zabiegali o interesy osobiste, czy przedstawiali żądania całego pospólstwa miejskiego. Wydaje się, że częściową odpowiedź mogą dać biogramy tych osób opracowane w oparciu o odnalezione informacje źródłowe.

49 Pochodził z Gostynin, był cechmistrzem cechu krawieckiego, prawo miejskie przyjął w 1557 r. (ibidem, nr 2445).

${ }^{50}$ Był starszym bratem w cechu (ibidem, nr 2554).

${ }^{51} \mathrm{~W}$ rejestrach prawa miejskiego są wzmianki o dwu osobach z takimi imionami: Stanisław Szewc z przedmieścia, który przyjął prawo miejskie w 1569 r. (ibidem, nr 2771); Stanisław Szewc (syn nieżyjącego już Macieja Hajduka), prawo miejskie przyjął w 1574 r. (ibidem, nr 2903).

${ }^{52}$ Był cechmistrzem cechu kowali w latach 1585-1589 (ibidem, nr 3093, 3095, 3162, 3181).

${ }^{53}$ W latach 1571-1603 występował jako poręczyciel (ibidem, nr 2822, 2969, 2977, 2984, 3003, 3016, 3047, 3188, 3191, 3272, 3296, 3338).

${ }^{54}$ Привілеї міста Львова XIV-XVIII cm., зб. док., упоряд. М. Капраль, Львів 1998, s. $387-$ 396 (nr 166). 


\section{JAN ZAIDLICZ}

Był wymieniany w źródłach i literaturze jako główny przywódca wystąpienia $^{55}$. Jedyny kupiec wśród przywódców opozycji mieszczańskiej. Oprócz tego był serwitorem królewskim i pełnił urząd sędziego żydowskiego. Miał liczne interesy z przedstawicielami stanu szlacheckiego, być może był szlachcicem.

Pochodził ze Lwowa. Wiadomo, że w 1549 r. został przyjęty do prawa miejskiego w tym mieście ${ }^{56}$. Jeżeli przyjąć, że mieszkańcy Lwowa uzyskiwali obywatelstwo wraz z osiągnięciem pełnoletniości, czyli w wieku 21 lat, możemy przypuszczać, że urodził się w końcu lat 20. XVI w. Pochodził z wybitnej rodziny patrycjuszowskiej. Jego matka, Ewa, była córką rajcy Mikołaja Tyczki ${ }^{57}$ i Barbary $\mathrm{z}$ domu Arnestowej ${ }^{58}$. Zaś ojciec, Mikołaj Zaidlicz, był złotnikiem ${ }^{59}$. Jego rodzeństwo również należało do grona wybitnych mieszkańców Lwowa. Siostra, Anna, była żoną włoskiego kupca Antonia Pandolfi ${ }^{60}$. Brat, Piotr, był członkiem cechu kuśnierzy $^{61}$. Na początku lat 60 . XVI w. Jan Zaidlicz ożenił się z Katarzyną ${ }^{62}$, córką ławnika Urbana Stanifusora ${ }^{63}$ i Klary Urbanowej ${ }^{64}$. Warto zauważyć, że pod 1538 r. Urbana wspomina się w księgach miejskich jako członka Kolegium „Dziesięciu mężów" - instytucji, przed którą rajcy corocznie składali sprawozdanie z działalności finansowej ${ }^{65}$. Prawdopodobnie Jan i Katarzyna mieli czworo dzieci: córkę Katarzynę ${ }^{66}$ oraz trzech synów - Jakuba ${ }^{67}$, Daniela ${ }^{68}$ i Tomasza ${ }^{69}$. Córkę Zaidlicz wydał w 1570 r. za Jerzego Glacza ${ }^{70}$, syna rajcy Jodoka Glacza ${ }^{71}$. Z zebra-

${ }^{55}$ CDIAUL, f. 9, op. 1, spr. 336, s. 1199 (25 stycznia 1577 r.), 1208 (15 marca 1577 r.). W obu wypadkach zapis zatytułowano Protestatio communitas contra consules. Zob. J. Ptaśnik, Walki o demokratyzację Lwowa od XVI do XVIII wieku, „Kwartalnik Historyczny” 1924, R. 38, s. 232.

${ }^{56}$ Album civium Leopoliensium..., $\mathrm{nr} 2231$.

${ }^{57}$ Był rajcą w latach 1503-1521. Zob. M. Kapral, op. cit., nr 142.

${ }^{58}$ CDIAUL, f. 52, op. 2, spr. 11, s. 1274; CDIAUL, spr. 238, s. 960 (1556 r.).

${ }^{59}$ CDIAUL, f. 52, op. 2, spr. 238, s. 958, 960 (1556 r.).

${ }^{60}$ CDIAUL, f. 52, op. 2, spr. 224, s. 965; CDIAUL, spr. 225, s. 391 (1554 r.).

${ }^{61}$ CDIAUL, f. 52, op. 2, spr. 225, s. 32, 88 (1552 r.), 393 (1554 r.).

${ }^{62}$ CDIAUL, f. 52, op. 2, spr. 26, s. 106; CDIAUL, spr. 225, s. 778 (1556 r.); CDIAUL, spr. 226, s. 734 (1571 r.).

${ }^{63}$ Był ławnikiem w latach 1540-1563. Zob. M. Kapral, op. cit., nr 527.

${ }^{64}$ Była córką Jana Neitera z Kamieńca (CDIAUL, f. 52, op. 2, spr. 224, s. 222 [1240 r.]).

${ }^{65}$ CDIAUL, f. 52, op. 2, spr. 704, s. 185.

${ }^{66}$ CDIAUL, spr. 26, ark. 106, 107 (1602 r.).

${ }^{67}$ CDIAUL, spr. 227, ark. 1108 (1599 r.); spr. 26, ark. 743 (1604 r.).

${ }^{68}$ CDIAUL, spr. 20, ark. 672 (1589 r.).

${ }^{69}$ Akta grodzkie i ziemskie z czasów Rzeczypospolitej Polskiej z archiwum bernardyńskiego we Lwowie, wydał X. Liske [et al.], t. 10, Lwów 1884 (dalej: AGZ), s. 164 (2534) (1591 r.).

${ }^{70}$ Ibidem, f. 52, op. 2, spr. 26, s. 106; Biblioteka Zakładu Narodowego im. Ossolińskich we Wrocławiu (dalej: Ossol.), Rękopisy, sygn. 826, Regestrum nuptiarum in ecclesia metropolitana Leopoliensi ab AD 1554 ad AD 1591, s. 58.

${ }^{71}$ Był rajcą w latach 1571-1589. Zob. M. Kapral, op. cit., nr 193). 
nych informacji wynika więc, że Jan Zaidlicz był związany z elitą władzy w mieście więziami pokrewieństwa i powinowactwa.

Zaidlicz posiadał znaczny majątek w mieście. Po śmierci swojego dziadka, rajcy Mikołaja Tyczki, uzyskał w spadku część kamienicy na Rynku² oraz dom na Przedmieściu Halickim ${ }^{73}$. Od swojego teścia, Urbana Stanifusora, uzyskał też pewne nieruchomości. W 1566 r., po śmierci ojca, jego żona, Katarzyna, uzyskała spadek - kamienicę przy rynku i ogród ${ }^{74}$. Jeszcze za życia Urbana Stanifusora Zaidlicz odkupił od niego ogród zwany Gieblowskim na Przedmieściu Krakowskim za $600 \mathrm{fl}^{75} \mathrm{~W}$ interesującym nas okresie posiadał także kamienicę koło cerkwi ruskiej ${ }^{76}$ oraz domy na placu Bydlęcym ${ }^{77}$ i przy ul. Szpitalnej ${ }^{78}$, ponadto dzierżawił wieś Siedliska u szlachetnego Hieronima Węgleńskiego ${ }^{79}$ i posiadał część wsi Podwysockie ${ }^{80}$.

Władysław Łoziński w swoim dziele zaliczył go do grona najbogatszych kupców. W latach 1550-1560 Zaidlicz był jednym z trzech kupców we Lwowie, którzy zajmowali się wywozem skór sobolich do Europy Zachodniej. Razem z Zebaldem Aichingerem transportowali towar do Wenecji ${ }^{81}$. Handlował również wołami, m.in. w 1559 r. uzyskał od mieszczanina krakowskiego Stanisława Giel-

${ }^{72}$ Była rozmieszczona między kamienicami Marcina Schongregiera i Magistra Simona; w 1552 r. odkupił on jeszcze jedną część tej kamienicy od swojego brata, Piotra (CDIAUL, f. 52, op. 2, spr. 11, s. 1274, 1617; CDIAUL, spr. 225, s. 32 [1552 r.]).

${ }^{73}$ Mieścił się na ul. Czarnej-Hanusowskiej (CDIAUL, f. 52, op. 2, spr. 225, s. 391 [1555 r.]; CDIAUL, spr. 238, s. 958, 1094 [1556 r.]).

${ }^{74}$ Kamienica była rozmieszczona na rynku koło kamienicy Melchiora Scholza, naprzeciw domu Abrkowskiego, zaś ogród - koło królewskiego źródła (CDIAUL, f. 52, op. 2, spr. 14, s. 880, 881, 925 [1567 r.]; CDIAUL, spr. 226, s. 734 [1571 r.]).

${ }^{75}$ Ogród mieścił się koło ogrodu Laurentia Cellara, naprzeciw ogrodu zwanego Kiczulnickim (CDIAUL, f. 52, op. 2, spr. 13, s. 172 [1561 r.]; CDIAUL, spr. 225, s. 778 [1556 r.]).

${ }^{76}$ Była położona koło cerkwi Ruskiej, między domami Błażeja Sochy i Filipa Ormianina. Kupił ją od Mikołaja i Jana, synów Mikołaja Dolińskiego, za 600 fl. (CDIAUL, f. 52, op. 2, spr. 14, s. 536, 1167; CDIAUL, spr. 226, s. 325 [1566 r.], 809 [1576 r.]).

${ }^{77}$ Dom mieścił się na placu Bydlęcym między domami Wojnarowskim i Pawła Czopechownego. Kupił go od Krzysztofa Mazancza za 800 fl. (CDIAUL, f. 52, op. 2, spr. 15, s. 1364 [1573 r.]; CDIAUL, spr. 226, s. 808 [1574 r.]; CDIAUL, spr. 227, s. 1108 [1599 r.]).

${ }^{78}$ CDIAUL, f. 52, op. 2, spr. 225, s. 541 (1555 r.).

79 Jako zapłatę za arendę Zaidlicz zobowiązał się spłacić w 1565 r. 220 fl., w 1566 r. -240 fl. (CDIAUL, f. 52, op. 2, spr. 14, s. 200-201).

${ }^{80}$ Zaidlicz pożyczył szlachetnemu Jakubowi Podwysockiemu za poręką sumę 3 tys. fl. W 1575 r. wobec niespłacenia długu Podwysocki zrezygnował z tych dóbr ziemskich. W latach 1573-1578 trwał spór sądowy między Zaidliczem a innymi właścicielami tej wsi: Michałem Podwysockim i jego synem Janem, Jadwigą Tarlową, Katarzyną Podchorecką (CDIAUL, f. 9, op. 1, spr. 335, s. 837, 849, 857-858, 1023-1024, 1053, 1195-1196; CDIAUL, spr. 336, s. 17, 18, 133, 181, 246, 398, 588, 603, 756, 795, 1194; CDIAUL, spr. 337, s. 164, 597, 1136).

${ }^{81}$ W. Łoziński, Patrycjat i mieszczaństwo lwowskie w XVI-XVII wiekach, Lwów 1890, s. 49; CDIAUL, f. 52, op. 2, spr. 11, s. 1339. 
chorna 2 tys. 800 fl. za jedno stado wołów ${ }^{82}$. Wkrótce w Sądzie Wyższym Prawa Magdeburskiego na Zamku Krakowskim toczył się proces między nimi o niespłacenie przez Zaidlicza długu 1 tys. fl. ${ }^{83}$ Zaidlicz zajmował się też handlem rybami ${ }^{84}$ oraz suknem (adamaszkiem i purpurą) ${ }^{85}$. Zapewne sprowadzał do Lwowa „towary wschodnie". Interesy finansowe łączyły go z kupcami tureckimi - Handzim Hassonem i Handzim Helim z Galaty ${ }^{86}$.

Jan Zaidlicz prowadził też interesy finansowe z Krzysztofem Moranczem ${ }^{87}$, Augustynem Aichingerem ${ }^{88}$ i Zebaldem Aichingerem ${ }^{89}$ ze Lwowa, Piotrem Danielem ${ }^{90}$ i Krzysztofem Szylingiem ${ }^{91}$ z Krakowa, Maciejem Chodeckim z Poznania $^{92}$, Filario Kropidłem z Wrocławia ${ }^{93}$ oraz nieznanym bliżej Stanisławem Ziwkowskim ${ }^{94}$. Brał często udział jako jednacz i opiekun w rozstrzyganiu spraw sądowych. Najczęściej był pełnomocnikiem kupców z innych miast - Mikołaja Waiszkowicza Ormianina z Kamieńca ${ }^{95}$, Fołtina Remera z Krosna ${ }^{96}$ oraz osób szlacheckiego pochodzenia: Jakuba Strzałkowskiego ${ }^{97}$, kasztelana przemyskiego Piotra Barziego ${ }^{98}$ i magnata Jana Zborowskiego ${ }^{99}$. Zaidlicz występował też przed sądem jako opiekun dzieci Włocha Antonia Pandolfiego ${ }^{100}$, a także majątku po śmierci Krystyny Muchinej ${ }^{101}$. Działalność ta świadczy o jego dużym autorytecie w mieście.

W 1565 r. Zaidlicz został wymieniony jako subdelegat w sądzie żydowskim $^{102}$. Sprawując tę funkcję, w 1571 r. toczył proces przed sądem królewskim

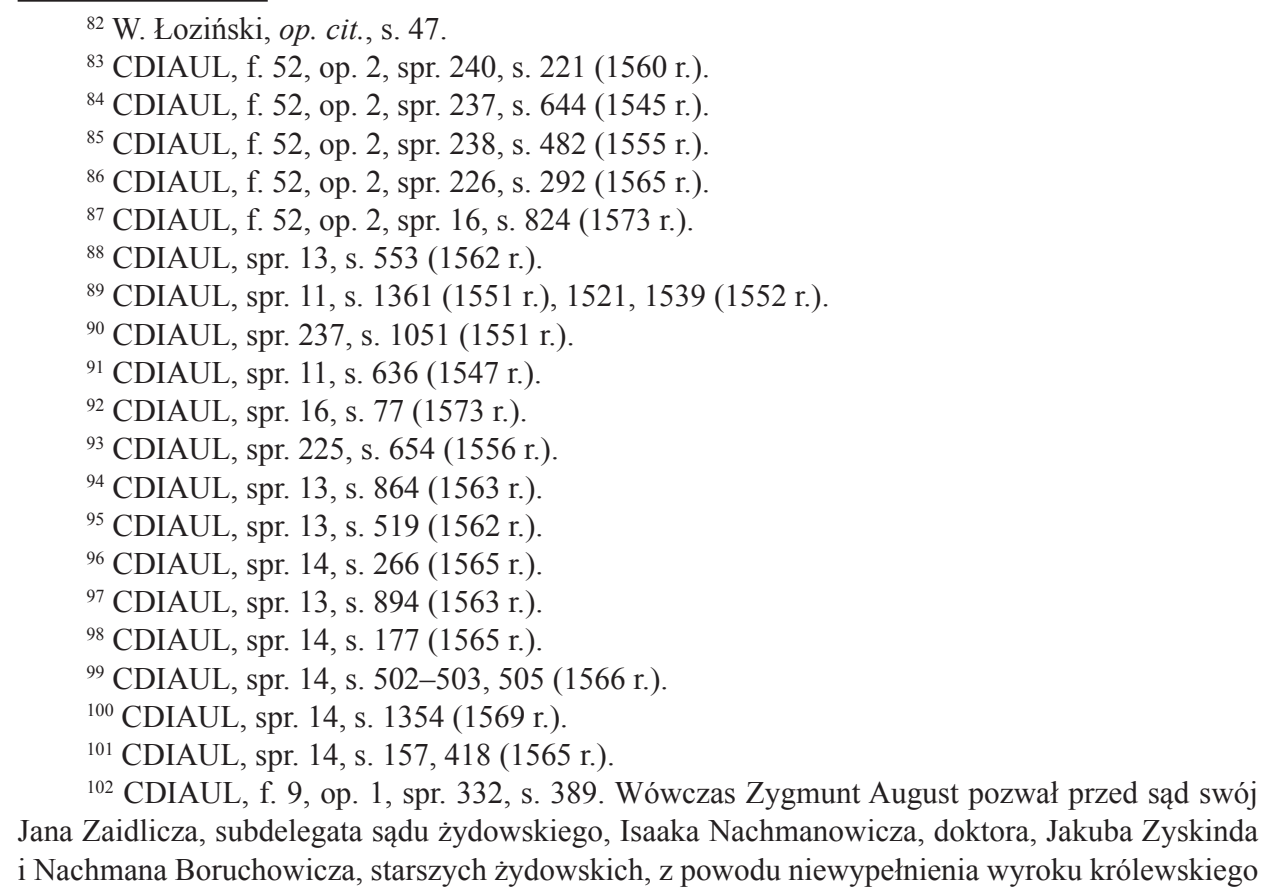

${ }^{102}$ CDIAUL, f. 9, op. 1, spr. 332, s. 389. Wówczas Zygmunt August pozwał przed sąd swój Jana Zaidlicza, subdelegata sądu żydowskiego, Isaaka Nachmanowicza, doktora, Jakuba Zyskinda i Nachmana Boruchowicza, starszych żydowskich, z powodu niewypełnienia wyroku królewskiego 
z Żydami lwowskimi. Żydzi oskarżyli go, że „chciał być ich sędzią, od pana wojewody Ruskiego na tym urzędzie postawionym". Król odwołał tę nominację i rozkazał, aby Zaidlicz pod karą 3 tys. fl. „nad Żydami żadnej jurysdykcji nie sprawował"103.

Spory sądowe i zatargi między radą miejską a Janem Zaidliczem miały miejsce jeszcze w początkach lat 70. XVI w. W $1573 \mathrm{r}$. skarżył się przed starostą, że z rozkazu rady siłą go zatrzymano, gdy wyjeżdżał w sprawach handlowych z miasta. Doprowadzono go do sądu miejskiego, chociaż miał nad nim wówczas jurysdykcję wyłącznie sąd kapturowy ${ }^{104}$. Protest w tej sprawie miał prawne uzasadnienie, Zaidlicz odwoływał się bowiem do mandatów królewskich nadanych mu kilka lat wcześniej. Wiadomo, że w 1569 r. król uwolnił go jako serwitora od jurysdykcji miejskiej i przekazał sądowi wojewody ruskiego, Jerzemu Jazłowieckiemu $^{105}$, a w 1571 r. ogłosił decyzję, że sprawy sądowe Zaidlicza miały podlegać wyłącznie sądom królewskim ${ }^{106}$. W tym samym roku król rozkazał, aby starosta lwowski Mikołaj Herburt Odnowski dopilnował, aby urząd miejski nie wyrządzał Zaidliczowi krzywdy ${ }^{107}$. Nadał mu też „list żelazny”108.

W latach 1576-1577 toczył się proces sądowy między Zaidliczem a radą miejską o majątek Wawrzyńca Morawińskiego. Dobra te po bezpotomnej śmierci właściciela według prawa kaduka zostały przekazane przez króla Piotrowi Zborowskiemu, wojewodzie i kasztelanowi krakowskiemu, a od niego dostały się w zarząd Jana Zaidlicza ${ }^{109}$. Rajcy według przywileju z 1555 r. ${ }^{110}$ uzyskali prawo rozporządzania majątkiem mieszczan niemających spadkobierców i mieli wykorzystywać go na potrzeby odbudowy miasta. $Z$ tego powodu prawdopodobnie sprzeciwiali się przejęciu powyższych nieruchomości przez Zaidlicza. W marcu 1577 r. król nakazał burmistrzowi i rajcom, aby wydali Zaidliczowi dobra Wawrzyńca Morawińskiego. Wzajemne procesy sądowe dotyczące tego majątku miały miejsce również później ${ }^{111}$.

\footnotetext{
wydanego w sporze Anny, wdowy po Andrzeju Haliczu, mieszczaninie krakowskim, z Lewkiem Czechem, Żydem lwowskim, o 105 zł. Zob. AGZ, nr 1308 (regest).

${ }^{103}$ CDIAUL, f. 52, op. 2, spr. 15, s. 661-664 (1571 r.).

${ }^{104}$ CDIAUL, f. 9, op. 1, spr. 335, s. 368-371.

${ }^{105}$ CDIAUL, f. 9, op. 1, spr. 334, s. 616; AGZ, nr 1511 (regest).

${ }^{106}$ CDIAUL, f. 9, op. 1, spr. 334, s. 716-718; AGZ, nr 1658 (regest).

${ }^{107}$ CDIAUL, f. 9, op. 1, spr. 334, s. 718-719; CDIAUL, spr. 335, s. 368-371; AGZ, nr 1661, 1663 (regest).

${ }^{108}$ CDIAUL, f. 9, op. 2, spr. 336, s. 868.

${ }^{109}$ CDIAUL, f. 9, op. 1, spr. 336, s. 1091, 1209.

${ }^{110}$ Привілеї міста Львова..., s. 344-345 (nr 150).

${ }^{111}$ CDIAUL, f. 9, op. 1, spr. 336, s. 1209 (16 marca 1577 r.), 1229 (20 marca 1577 r.).
} 
W latach 1563-1588 trwał proces sądowy między Janem Zaidliczem i Markusem Majerem, Żydem z Poznania ${ }^{112}$. Poręczył za niego i domagał się prawa do przejęcia jego towarów na sumę 1200 fl., które w 1564 r. zostały zajęte we Lwo$w^{11}{ }^{113}$. W 1576 r. w sądzie grodzkim lwowskim Zaidlicz oskarżył rajców lwowskich, że nie chcieli zgodzić się na apelację w sprawie z Markusem Majerem do monarchy, co jemu jako serwitorowi królewskiemu przysługiwało, miał bowiem glejt bezpieczeństwa stanowiący o podległości wyłącznie sądom królewskim ${ }^{114}$. Zapewne w tym sporze rajcy trzymali stronę Markusa Majera albo tylko chcieli mu przysporzyć trudności, stąd jego protest i domaganie się zgody na apelację do sądu królewskiego. W 1580 r. proces ostatecznie przybrał obrót niekorzystny dla Zaidlicza. Rada miejska wydała wyrok przyznający Żydowi Majerowi prawo do majętności Zaidlicza na sumę 2 tys. fl. ${ }^{115}$ Katarzynie Zaidliczowej pozostawiono tylko 1/3 część rodzinnych dóbr Zaidliczów i część domu na Przedmieściu Krakowskim ${ }^{116}$. W 1586 r. Markus Mejer przekazał prawa do majątku Zaidlicza szlachcicowi Piotrowi Boreckiemu, podczaszemu halickiemu ${ }^{117}$. Dopiero w 1588 r. Borecki zrzekł się tej własności na rzecz Daniela, syna Jana Zaidlicza - mieszczanina krakowskiego ${ }^{118}$. Wynika z tego, że po konflikcie z lat $1576-1577$ rada miejska nadal była niechętna Zaidliczowi i doprowadziła do tego, że wyzbył się on majętności we Lwowie. W 1581 r. sprawa ta trafiła z kolei do sądu królewskiego. Wówczas król nakazał radzie miejskiej, pod karą 2 tys. zł, wykonać wydany poprzednio wyrok dotyczący Jana Zaidlicza i Markusa Majera ${ }^{119}$. Niestety, nie znamy jego treści.

Prawdopodobnie przyczyną tych trudności i procesów była postawa Zaidlicza wobec rady oraz jego udział w procesie pospólstwa. Warto też wspomnieć, iż jeszcze w 1558 r. razem z Janem Herburtem z Fulsztyna (kasztelanem sanockim), Janem Brzozowskim (podsędkiem lwowskim) i Janem Rychłowskim (pisarzem ziemskim buskim) wchodził Zaidlicz w skład komisji, która miała czuwać nad poprawą funkcjonowania miast i miasteczek starostwa lwowskiego ${ }^{120}$. Komisja mia-

${ }^{112}$ Markus (Merci) Majer był powiązany z Isaakiem Nachmanowiczem, zwłaszcza jego syn Bernab, który był zięciem Nachmanowicza (CDIAUL, f. 52, op. 2, spr. 18, s. 498-499 [1581 r.]).

${ }^{113}$ CDIAUL, spr. 13, s. 960.

${ }^{114}$ CDIAUL, spr. 336, s. 868-869 (1576 r.).

${ }^{115}$ Zwłaszcza Markus Majer uzyskał wprowadzenie w posiadanie na kamienicę za ul. Ruską między Filipa Ormianina i Dominika Chepnera Chirurga, dom i ogród na Przedmieściu Krakowskim, za ul. Żydowską, koło domu Pawła Jelonka i naprzeciw sadu Wilhelma Allandta Kizilińskiego (CDIAUL, f. 52, op. 2, spr. 18, s. 6, 428-432).

${ }^{116}$ CDIAUL, f. 52, op. 2, spr. 18, s. 429 (1582 r.).

${ }^{117}$ CDIAUL, spr. 18, s. 498-499 (1582 r.); CDIAUL, spr. 19, s. 880-881 (1586 r.).

${ }^{118}$ CDIAUL, spr. 20, s. 672 (1589 r.).

${ }^{119}$ CDIAUL, f. 9, op. 1, spr. 73, s. 753-754; CDIAUL, spr. 342, s. 951-952 (1581 r.); AGZ, nr 2140 (regestr).

${ }^{120}$ CDIAUL, f. 9, op. 1, spr. 36, s. 429-431 (1558 r.); AGZ, nr 1412 (regestr). 
ła kontrolować działalność finansową rajców i to mogło być powodem konfliktu Zaidlicza z rajcami lwowskimi.

W 1578 r., już po wystąpieniu z pospólstwa, Jan Zaidlicz zrzekł się prawa miejskiego we Lwowie. Należy zauważyć, że rada mogła wykluczyć osobę z grona obywateli tylko z powodu niewywiązywania się ze zobowiązań związanych z obywatelstwem ${ }^{121}$. Jan Zaidlicz 31 maja 1578 r. sam jednak zrezygnował z obywatelstwa miejskiego, chociaż jednocześnie został pozbawiony prawa miejskiego przez radę miejską ${ }^{122}$. W celu zrzeczenia się obywatelstwa Zaidlicz przybył do rady miejskiej w obecności Baltazara Ożgi (podstarościego lwowskiego), Stanisława Cieszanowskiego, woźnego Jana Wilczka i jeszcze dwóch szlachciców - Józefa Gościckiego i Bartłomieja Krzyżanowskiego ${ }^{123}$. Dopiero po jego ogłoszeniu woli, tego samego dnia rada pozbawiła go wszystkich praw związanych z obywatelstwem ${ }^{124}$. W tym samym roku pojawiła się wzmianka o Janie Zaidliczu jako szlachcicu i poborcy podatków ziemi lwowskiej ${ }^{125}$. Możemy więc przypuszczać, że akt zrzeczenia się był powiązany z chęcią uzyskania pełni praw szlacheckich, czego prawdopodobnie był on pewny. W latach 80. XVI w. w księgach radzieckich lwowskich już nie występuje. Podatki za należące do niego nieruchomości od 1578 r. płaciła jego żona, Katarzyna ${ }^{126}$. Z trojga dzieci tylko córka Katarzyna, która była żoną Jerzego Glacza, nadal mieszkała we Lwowie ${ }^{127}$. Synowie natomiast przeprowadzili się do innych miast - Jakub został mieszczaninem warszawskim $^{128}$, a Daniel - krakowskim ${ }^{129}$. Wiadomo, że Daniel w latach 1615-1630 wchodził do składu krakowskiej rady miejskiej ${ }^{130}$, a jego syn Mikołaj, czyli wnuk Jana Zaidlicza, najpierw był ławnikiem ${ }^{131}$, a od $1631 \mathrm{r}$. został wybrany do rady miejskiej ${ }^{132}$. Odnaleziono też znikome wzmianki o działalności trzeciego syna Tomasza. Wiadomo, że w 1591 r. zwrócił się on do króla Zygmunta III z prośbą

121 О. Заяць, Громадяни Львова ХІV-XVIII ст.: правовий статус, склад, походження, Київ - Львів 2012, s. 137.

${ }^{122}$ CDIAUL, f. 52 , op. 2, spr. 648, s. 62-63.

${ }^{123}$ Ibidem.

${ }^{124}$ Album civium Leopoliensium ..., nr 2994.

${ }^{125}$ CDIAUL, f. 9, op. 1, spr. 337, s. 1129, 1243, 1319, 1384 (1578 r.).

${ }^{126}$ CDIAUL, f. 52, op. 2, spr. 702 , s. 44 (1578 r.), 58 (1579 r.), 73 (1580 r.), 87 (1581 r.), 103 (1582 r.), 177 (1586 r.), 199 (1587 r.), 219 (1588 r.).

${ }^{127}$ CDIAUL, f. 52, op. 2, spr. 26, s. 106, 107 (1601 r.).

${ }^{128}$ CDIAUL, spr. 227, s. 1108 (1599 r.). Do rejestrów przyjęć do prawa miejskiego Warszawy został wpisany 7 lutego 1575 r. Zob. Album civium Antiquae Varsoviae. Księga przyjęć do prawa miejskiego Starej Warszawy 1506-1586, oprac. A. Bartoszewicz, Warszawa 2000, nr 1551.

${ }^{129}$ Do rejestrów przyjęć do prawa miejskiego Krakowa został wpisany 25 września $1579 \mathrm{r}$. Zob. Księgi przyjęć do prawa miejskiego w Krakowie 1573-1611. Libri iuris civilis Cracoviensis 1573-1611, wyd. A. Kiełbicka, Z. Wojas, Kraków 1994, nr 461.

${ }^{130}$ Urzędnicy miejscy Krakowa, cz. 2: 1500-1794, oprac. Z. Noga, Kraków 2008, nr 189.

${ }^{131}$ Ibidem, nr 619.

${ }^{132}$ Ibidem, nr 216. 
o udzielenie mu listu bezpieczeństwa i ochrony jego mienia od szlachetnych Mikołaja Ostrowskiego, Grzegorza Podwysockiego, Iwana Lubomirskiego, Iwana Michalewicza i Ignata Jacka ${ }^{133}$. Widocznie objął on ziemskie majętności swojego ojca (wieś Podwysockie) i prowadził interesy ze szlachtą.

Wydaje się, że Jan Zaidlicz jako postać w mieście znana i bogata, a także powiązana z elitą władzy (był wnukiem rajcy), chciał otrzymać urząd miejski. Jeśli założyć, że urodził się on w latach 20. XVI w., możemy przyjąć, że w czasie konfliktu (1576-1577) był już w podeszłym wieku. Z powodu licznych sporów z rajcami, nie mając szans na wybór do ławy, stanął więc na czele niezadowolonych. Na nieprzejednaną postawę Jana Zaidlicza wobec rajców chyba miał wpływ fakt, iż był on serwitorem królewskim i miał powiązania z przedstawicielami stanu szlacheckiego. Następnie powrócił w szeregi szlachty.

\section{JAN GANSZORN}

Drugim pod względem zamożności przywódcą pospólstwa lwowskiego w wydarzeniach lat 1576-1577 był Jan Ganszorn. Powiązany z grupą rządzącą Lwowa, był również kontynuatorem dawnego patrycjuszowskiego rodu ${ }^{134}$. Jego matka, Anna, była córką bogatej mieszczki lwowskiej, Zofii Temriczowej ${ }^{135}$. Ojciec był kuśnierzem, który przybył do Lwowa z miasta Wurtsburg i w $1533 \mathrm{r}$. przyjął prawo miejskie ${ }^{136}$. Siostra jego matki Anny - Emerancia, była żoną rajcy Jana Grynwalta ${ }^{137}$, a jego ojczym, drugi mąż Anny (matki) - Jan Scholz, był ławnikiem w latach 1553-1576 $6^{138}$. Trudno ustalić, ile lat miał Jan Ganszorn w czasie konfliktu. Do rejestrów przyjętych do prawa miejskiego został wpisany w 1570 r. ${ }^{139}$ Jeszcze w 1568 r. ożenił się z Katarzyną Hajdukówną ${ }^{140}$, lecz nie wiadomo, czy była ona jego pierwszą żoną. Następnie dwukrotnie zawierał małżeństwa - z Barbarą, matką jego syna Grzegorza ${ }^{141}$, oraz Agnieszką, która po jego śmierci została żoną szlachetnego Macieja Łękawskiego z Opola ${ }^{142}$.

${ }^{133}$ CDIAUL, f. 9, op. 1, spr. 350, s. 631; AGZ, s. 164 (2534; regestr).

${ }^{134}$ Przedstawiciele rodu Temriczów jeszcze w końcu XV i na początku XVI w. byli członkami władz miejskich: Mikołaj Temricz był rajcą (1472-1477), Piotr Temricz - ławnikiem (1515-1521). Zob. M. Kapral, op. cit., nr 115, 492. Prawdopodobnie ten ostatni był mężem Zofii Temriczowej, czyli dziadkiem Jana Ganszorna.

${ }^{135}$ CDIAUL, f. 52, op. 2, spr. 224, s. 166; CDIAUL, spr. 226, s. 418 (1568 r.).

${ }^{136}$ Album civim Leopoliensium ..., nr 1820.

${ }^{137}$ Był rajcą w latach 1545-1553. Zob. M. Kapral, op. cit., nr 171.

${ }^{138}$ CDIAUL, f. 52, op. 2, spr. 13, s. 319 (1561 r.), 821 (1563 r.); CDIAUL, spr. 226, s. 895 (1577 r.); M. Kapral, op. cit., nr 548.

${ }^{139}$ Album civium Leopoliensium ..., nr 2794.

${ }^{140}$ Ossol. rkps $\mathrm{nr} 826$, Regestrum nuptiarum in ecclesia metropolitana Leopoliensis ab AD 1554 ad AD 1591, s. 52; CDIAUL, f. 52, op. 2, spr. 226, s. 732.

${ }^{141}$ CDIAUL, f. 52, op. 2, spr. 227, s. 733 (1590 r.).

${ }^{142}$ CDIAUL, spr. 227, s. 911 (1592 r.). 
Jan, podobnie jak jego ojciec, Jerzy Ganszorn, był kuśnierzem. W latach $1581,1582,1585,1589$ był cechmistrzem cechu kuśnierzy ${ }^{143}$. W latach $1588-$ 1589 był kontrolerem jakości sukna ${ }^{144}$. Obok wykonywania zawodu zajmował się również działalnością finansową. Pożyczki pod zastaw domów i innych nieruchomości udzielał mieszczanom i szlachcie. Prowadził interesy finansowe ze szlachtą: Franciszkiem Natkowskim ${ }^{145}$, Mikołajem Nachajowskim ${ }^{146}$, Adamem Wolskim, ${ }^{147}$ Steczkom Bilińskim ${ }^{148}$, oraz z mieszczanami: Hanusem Loji Węgrem z Braszki ${ }^{149}$, Maciejem Owieczką z Kazimierza ${ }^{150}$, Walentym Czupiłowiczem ${ }^{151}$, dr. Pawłem Nowikampianem ${ }^{152}$, Hanusem Krawcem ${ }^{153}$, Steczkiem Szymkowiczem $^{154}$, Jaworem Kalinowskim ${ }^{155}$, Albertem Pajączkiem ${ }^{156}$ oraz innymi mieszczanami i mieszkańcami przedmieść lwowskich ${ }^{157}$. Część transakcji pieniężnych przeprowadzał wraz z innym cechmistrzem cechu kuśnierzy, Jakubem Ogorzałkiem ${ }^{158}$. Oprócz tego zajmował się handlem, m.in. rybami solonymi. Transakcje handlowe związane z tym towarem przeprowadzał z kupcami lwowskimi: Sebastianem Zielińskim ${ }^{159}$ i Leonardem Linderbatem ${ }^{160}$.

Obok działalności gospodarczej Jan Ganszorn prowadził aktywną działalność społeczną. Od 1575 r. często występował w sądzie jako jednacz ${ }^{161}$, poręczy-

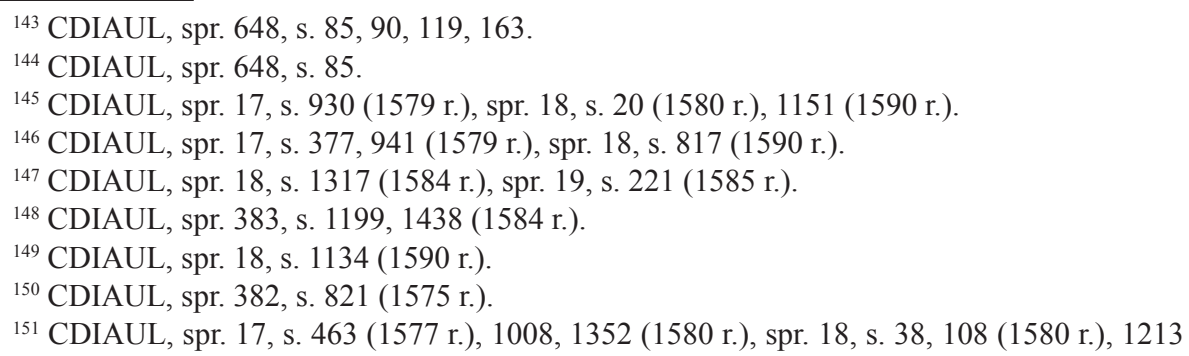
(1584 r.).

${ }^{152}$ CDIAUL, spr. 13, s. 632 (1562 r.), spr. 20, s. 957 (1590 r.).

${ }^{153}$ CDIAUL, spr. 18, s. 734, 743 (1582 r.), 1140 (1584 r.).

${ }^{154}$ CDIAUL, spr. 383, s. 906 (1580 r.).

${ }^{155}$ CDIAUL, spr. 383, s. 1428 (1581 r.).

${ }^{156}$ CDIAUL, spr. 226, s. 911,924 (1570 r.).

${ }^{157}$ CDIAUL, spr. 13, s. 751, 768, 898 (1563 r.); spr. 19, s. 458, 466 (1586 r.), 626, 721 (1587 r.), 1232 (1584 r.); spr. 20, s. 507, 737 (1589 r.); spr. 21, s. 185 (1591 r.); spr. 382, s. 300, 377 (1576 r.), 507, 764, 786 (1577 r.); spr. 383, s. 74, 139, 205 (1579 r.), 399, 456 (1580 r.).

${ }^{158}$ CDIAUL, spr. 18, s. 1139, 1407 (1584 r.); CDIAUL, spr. 19, s. 289 (1585 r.), 834 (1587 r.); CDIAUL, spr. 20, s. 953, 1047, 1077 (1590 r.).

${ }^{159}$ CDIAUL, spr. 16, s. 1037, 1077 (1577 r.).

${ }^{160}$ CDIAUL, spr. 382, s. 138 (1574 r.).

${ }^{161} \mathrm{~W}$ sprawie między cechem kuśnierzy i Simonem Foltinkiem kuśnierzem zob. CDIAUL, f. 52, op. 2, spr. 20, s. 1442 (1590 r.). 
ciel $^{162}$ i plenipotent ${ }^{163}$. Jeszcze częściej był opiekunem dzieci i majątku obywateli Lwowa - Alberta Pajączka ${ }^{164}$, Piotra Dunajowskiego ${ }^{165}$, rajcy Jakuba Reguli ${ }^{166}$, Jana Scholzowicza ${ }^{167}$, Stanisława Augustynowicza ${ }^{168}$, szlachcica Melchiora Gajeczkiego ${ }^{169}$, Bartłomieja Kotha rzeźnika ${ }^{170}$, Jerzego krawca ${ }^{171}$, Alberta Wójcika ${ }^{172}$ i Stanisława Birkowskiego ślusarza ${ }^{173}$. Może to świadczyć o jego dużym autorytecie wśród współobywateli.

Ganszorn posiadał liczne nieruchomości w mieście. Po śmierci matki Anny i babki Zofii Temriczowej, razem z siostrą Anną ${ }^{174}$ odziedziczyli część kamienicy Temriczowskiej przy rynku ${ }^{175}$, dwa ogrody na Przedmieściu Halickim, czyli tzw. dobra Temriczowskie ${ }^{176}$, a po śmierci ojca - majątek również na tym przedmieściu ${ }^{177}$. W 1570 r. Ganszorn odkupił od swej ciotki Emerancji Grunwaltowej i jej drugiego męża, Sebastiana Zieleńskiego, ogród za 120 fl. ${ }^{178}$ oraz jej część w kamienicy Temriczowskiej (piwnicę) ${ }^{179}$. Po ślubie z Katarzyną Hajdukówną ${ }^{180}$ majątek Jana Ganszorna zwiększył się jeszcze o jedną kamienicę ${ }^{181}$. W tym czasie

162 Razem z Grekiem Markusem Langiszem poręczyli za przedmieszczanina Adama Klainowskiego (CDIAUL, f. 52, op. 2, spr. 17, s. 866 [1579 r.]); był również poręczycielem za Sebastiana Zieleńskiego (CDIAUL, f. 52, op. 2, spr. 17, s. 721-722 [1579 r.], 1052 [1580 r.]).

${ }^{163}$ Był pełnomocnikiem szlachcica Bartłomieja Słonki (CDIAUL, f. 52, op. 2, spr. 19, s. 331 [1585 r.]; CDIAUL, spr. 20, s. 608 [1589 r.]).

${ }^{164}$ CDIAUL, spr. 16, s. 1040 (1577 r.).

${ }^{165}$ CDIAUL, spr.19, s. 242 (1585 r.).

${ }^{166}$ CDIAUL, spr. 20, s. 126 (1589 r.).

${ }^{167}$ CDIAUL, spr. 19, s. 304-306 (1586 r.).

${ }^{168}$ CDIAUL, spr. 19, s. 1257 (1588 r.).

${ }^{169}$ CDIAUL, spr. 19, s. 349 (1585 r.).

${ }^{170}$ CDIAUL, spr. 19, s. 874, 916 (1587 r.).

${ }^{171}$ CDIAUL, spr. 20, s. 192 (1589 r.).

${ }^{172}$ CDIAUL, spr. 20, s. 108 (1589 r.).

${ }^{173}$ Ibidem, s. 70 (1589 r.).

${ }^{174}$ Była żoną Kaspara Morena (CDIAUL, spr. 13, s. 821, 898 [1563 r.]).

${ }^{175}$ Była położona na rynku między kamienicą Pelczinską i Alberta Olbrichta. Kamienica była szacowana na 1500 fl.; po śmierci Zofii Temriczowej została podzielona na trzy części między troje jej dzieci - Annę Ganszornową, Emerancję Grynwaltową oraz Stefana Temricza (CDIAUL, spr. 345, s. 216 [1562 r.]); część kamienicy swojej matki Anny - Jan Ganszorn i siostra Anna sprzedali sąsiadowi Pawłowi Nowikampianowi za 500 fl. (CDIAUL, spr. 226, s. 404 [1570 r.]).

${ }^{176}$ Łan należący do majątku Temriczowskiego Jan Ganszorn razem z siostrą Anną sprzedali za 300 talarów Pawłowi Nowokampianowi (CDIAUL, spr. 226, s. 409 [1570 r.]); z dwóch ogrodów na ul. Temriczowskiej Ganszorn jeden sprzedał Mikołajowi Gelasinowi (CDIAUL, spr. 226, s. 252 [1569 r.]), a drugi - Christoferowi Skliarzowi (CDIAUL, spr. 226, s. 418 [1570 r.]).

${ }^{177}$ CDIAUL, spr. 13, s. 821 (1563 r.).

${ }^{178}$ Mieścił się koło strzelnicy Pawła Jelonka i Jerzego Mildta (CDIAUL, spr. 15, s. 143, 231 [1570 r.]).

${ }^{179}$ CDIAUL, spr. 15, s. 635 (1571 r.).

${ }^{180}$ Jej pierwszy mąż to Albert Sobótka, szewc (CDIAUL, spr. 15, s. 41 [1570 r.]).

${ }^{181}$ Była położona między domem Simona Pisarza i cmentarzem Kościoła Metropolitalnego, 1/3 część tej kamienicy była własnością Katarzyny, a kolejną 1/3 Jan i Katarzyna odkupili od jej brata, 
nabył też dom na ul. Garncarskiej, który wkrótce sprzedał za 120 fl. Szymonowi Gniaczko ${ }^{182}$. Oprócz tego, już po śmierci Jana, jego spadkobiercy - syn Grzegorz i druga żona Agnieszka ${ }^{183}$ - przejęli posiadłości, które po nim odziedziczyli. Grzegorz miał dwa domki na Górze Kaliczej ${ }^{184}$ i dom na ul. Halickiej ${ }^{185}$, a Agnieszka-kamienicę Ganszornowską ${ }^{186}$.

Jako osoba spokrewniona $\mathrm{z}$ dawnym rodem patrycjuszowskim Temriczów, Jan Ganszorn był ściśle powiązany z przedstawicielami elity władzy Lwowa. Tak jak jego ojczym, Jan Scholz, był ławnikiem, więc znał działalność i sytuację prawną w gminie miejskiej. Stanem majątkowym Ganszorn dorównywał bogatym obywatelom Lwowa. Będąc cechmistrzem cechu kuśnierzy, jednego z najbogatszych cechów, mógł liczyć na wsparcie kolegów w cechu oraz przedstawicieli innych organizacji zawodowych.

\section{JAKUB SOSZKA}

Trzecim przywódcą, biorąc pod uwagę prestiż w mieście i stan majątkowy, a drugim w kolejności wymienionym w dekrecie malborskim był Jakub Soszka, także kuśnierz. On również miał powiązania rodzinne z członkami władz miejskich. Był synem cechmistrza cechu kuśnierzy, Macieja Sochy, który w latach 1557-1585 zasiadał w ławie sądowej ${ }^{187}$. Już po wydarzeniach konfliktowych, w latach 1583-1585, Jakub Soszka został cechmistrzem cechu kuśnierzy ${ }^{188}$. Prawo miejskie Soszka przyjął w 1569 r. ${ }^{189}$, a w następnym roku ożenił się z Agnieszką Nazurkówną ${ }^{190}$. Prawdopodobnie w czasie wydarzeń lwowskich był w dość młodym wieku.

Majątek Jakuba Soszki nie był tak duży, jak poprzednio wymienionych przywódców pospólstwa. Ze swoim szwagrem, Tomaszem Birkowskim ${ }^{191}$, był współ-

Macieja Hajduka (CDIAUL, spr. 15, s. 617, 678 [1571 r.]; CDIAUL, spr. 227, s. 173 [1579 r.]); 1/3 część była też własnością Alberta Słapkowskiego i jego żony, Doroty, w 1581 r. Ganszorn odkupił ją za 310 fl. (CDIAUL, spr. 15, s. 675, 709 [1571 r.]; CDIAUL, spr. 16, s. 776 [1574 r]), 1002 [1577 r.]; CDIAUL, spr. 17, s. 850 [1579 r.]; CDIAUL, spr. 18, s. 323, 324 [1580 r.]; CDIAUL, spr. 226, s. 753, 815 [1571 r.]; CDIAUL, spr. 382, s. 55 [1574 r.]).

${ }^{182}$ CDIAUL, spr. 15 , s. 626-627 (1571 r.).

${ }^{183}$ Drugim jej mężem był szlachcic Marcin Lękawski (CDIAUL, spr. 21, s. 1535 [1592 r.]; CDIAUL, spr. 22, s. 80, 159 [1593 r.]; CDIAUL, spr. 23, s. 609 [1595 r.]).

${ }^{184}$ CDIAUL, spr. 22, s. 661 (1594 r.); CDIAUL, spr. 23, s. 609 (1595 r.).

${ }^{185}$ Mieścił się koło cmentarza, między domami Ziółkowskiego i Sacerdotalem (CDIAUL, spr. 22, s. 181 [1592 r.], 1129 [1593 r.]; CDIAUL, spr. 227, s. 733 [1592 r.]).

${ }^{186}$ CDIAUL, spr. 22, s. 80, 159, 574 (1593 r.).

${ }^{187}$ M. Kapral, op. cit., nr 554.

${ }^{188}$ CDIAUL, spr. 648, s. 100, 106, 119.

${ }^{189}$ Album civium Leopoliensium ..., nr 2764.

${ }^{190}$ Ossol. rkps nr 826, Regestrum nuptiarum..., s. 52.

${ }^{191}$ Był synem Mikołaja Birkowskiego - przedstawiciela pospólstwa w Kolegium Decemwirum 
dziedzicem majątku ojca, Macieja Sochy ${ }^{192}$. Dzieciom, jakie miał z żoną Agnieszką, a więc córce Elżbiecie ${ }^{193}$ i synom: Jakubowi, Krzysztofowi, Janowi i Aleksandrowi, Soszka zostawił 1/3 część kamienicy Habermanowskiej przy rynku, którą uzyskał po ojcu ${ }^{194}$. W 1594 r. Agnieszka, wdowa po nim, i ich córka Elżbieta sprzedali Pawłowi Nowokampianowi część posiadłości na Górze Kaliczej, którą chyba też odziedziczyli po ojcu ${ }^{195}$. Jakub Soszka kilkakrotnie występował jako opiekun, m.in. majątku Feliksa Warnika ${ }^{196} \mathrm{i}$ jego nieletniej córki Anny ${ }^{197}$ oraz dzieci Kaspra Scholza ${ }^{198}$. Nie posiadamy informacji o prowadzeniu przez niego transakcji finansowych.

Jako syn ławnika Jakub Soszka, podobnie jak poprzednio wymienieni przywódcy pospólstwa, mógł starać się o miejsce w ławie sądowej, ale nie mogąc tego uzyskać, wystąpił przeciwko grupie rządzącej.

\section{JAN SZOLCZIK}

O czwartym przywódcy mieszczan w źródłach nie znaleziono żadnych wiadomości. Nie ma również wzmianki o przyjęciu go do prawa miejskiego ${ }^{199}$. Wiadomo tylko, że był krawcem. Figuruje jako przedstawiciel pospólstwa w dekrecie malborskim ${ }^{200}$, brał więc aktywny udział w interesujących nas wydarzeniach. Został również wymieniony w spisie rzemieślników - przywódców, którzy zachęcali pospólstwo do otwartego wystąpienia przeciwko radzie w sierpniu 1576 r. ${ }^{201}$

(instytucji składającej się z sześciu ławników i czterech przedstawicieli pospólstwa, którzy corocznie podczas wyborów słuchali sprawozdania z działalności rady miejskiej) w 1530, 1538 i 1552 r. Był wybitnym mieszczaninem, dwaj jego synowie - Fabian i Szymon - zdobyli wykształcenie wyższe na Uniwersytecie Krakowskim: Fabian z tytułem doktora, a Szymon - bakałarza. Wkrótce Fabian wstąpił do Zgromadzenia Franciszkanów i został kaznodzieją króla Władysława IV. Szymon kontynuował studia na Akademii Zamojskiej oraz w Padwie i pracował w Zamościu. Zob. J. Ptaśnik, Wiadomości o trzech lwowskich padewczykach. Odbitka z „Prac Polonistycznych” ofiarowanych prof. Janowi Łosiowi, Warszawa 1927, s. 195-206.

${ }^{192}$ CDIAUL, f. 52, op. 2, spr. 18, s. 331 (1581 r.); CDIAUL, spr. 21, s. 946 (1592 r.).

${ }^{193}$ Elżbieta była żoną Marcina Bonusa Chirurga (CDIAUL, spr. 22, s. 48 [1592 r.], 1314 [1594 r.]; CDIAUL, spr. 26, s. 745 [1603 r.]; CDIAUL, spr. 227, s. 749 [1585 r.]).

${ }^{194}$ Była położona między kamienicami Simona Magistra i Kaspara Gulińskiego (CDIAUL, spr. 22, s. 48 [1593 r.], spr. 227, s. 749, 750 [1585 r.]).

195 Była położona między Macieja Schorsa (kuśnierza) i Wolfganga (Bernta ławnika) (CDIAUL, spr. 22, s. 1314 [1594 r.]).

${ }^{196}$ CDIAUL, spr. 19, s. 59, 60 (1585 r.).

${ }^{197}$ CDIAUL, spr. 16, s. 1211, 1212 (1577 r.).

${ }^{198}$ CDIAUL, spr. 21, s. 868 (1592 r.).

${ }^{199}$ Album civium Leopoliensium...

${ }^{200}$ Привілеї міста Львова ..., s. 387-396 (nr 166).

${ }^{201}$ CDIAUL, f. 9, op. 1, spr. 336, s. 1259-1260 (8 września 1576 r.). 
Nie posiadamy wiadomości o jego życiu rodzinnym czy działalności w gminie miejskiej.

Jan Niedźwiedź i Jan Orzeszek, kolejni przywódcy, nieprzypadkowo zostali połączeni spójnikiem w treści dekretu i wymienieni jako ostatni wśród przywódców opozycji. W taki sposób chciano ich oddzielić od wymienionych dwóch mieszkańców przedmieść. Ich obecność w tym spisie świadczy o zaangażowaniu także przedmieszczan po stronie pospólstwa miejskiego.

\section{JAN NIEDŹWIEDŹ}

Reprezentował cech garbarzy, którego był cechmistrzem w latach 1578 , 1581-1586 202 , co dodatkowo świadczy o jego znaczeniu i autorytecie. Pochodził z rodziny rzemieślniczej. Jego bracia również zajmowali się wytwórczością: Walenty był bednarzem ${ }^{203}$, Wojciech - szewcem ${ }^{204}$, a Adam z Nadwórny - garbarzem $^{205}$. Nie posiadamy informacji o ich rodzicach.

Prawo miejskie przyjął w 1568 r. ${ }^{206}$ Jako członek cechu garbarskiego był dość bogaty. Posiadał duży majątek nieruchomy. Po ojcu razem z braćmi odziedziczył dom Strachowski za jatką rzeźniczą ${ }^{207}$. W 1570 r. wykupił część brata, Walentego $^{208}$. Od ojca swej żony, Doroty ${ }^{209}$ - Mikołaja Palucha, otrzymał dom z ogrodem na ulicy Sokolnickiej ${ }^{210}$. Był właścicielem w różnym czasie następujących nieruchomości: domów na Przedmieściu Halickim, pierwszego - między domami Lekarskiego i Marcina Rymarza ${ }^{211}$, drugiego - za bramą Halicką koło domu Zebalda Ślusarza ${ }^{212}$, trzeciego - na ul. Ślusarskiej ${ }^{213}$, czwartego - na ul. Temriczowskiej ${ }^{214}$, piątego - na ul. Garbarskiej za młynem browarskim ${ }^{215}$; domków z ogrodami: na

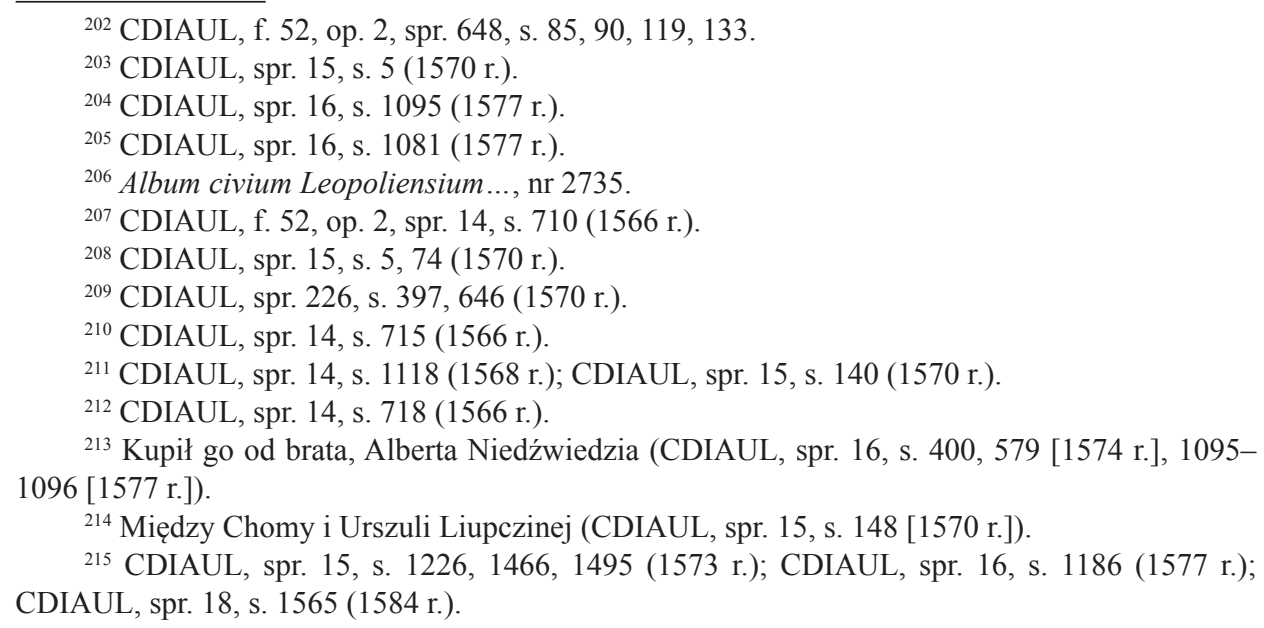


górze Kaliczejej ${ }^{216}$, na ul. Temriczowskiej ${ }^{217}$; działki na Przedmieściu Halickim - na ul. Garbarskiej ${ }^{218}$.

Niedźwiedź prowadził również działalność finansową. Odnaleziono informacje o jego licznych transakcjach pieniężnych: z szewcami lwowskimi Janem Szymonowicem i Sebastianem Sobkiem, krawcem Maciejem Michałowskim, Janem Żórawskim, Albertem Myszką, Maciejem Jakubowiczem, Janem Judaszkiem, Walentym Bednarzem, Michałem Kotlarzem, oraz szlachtą: Janem Kalinowskim i Filipem Szczepanowskim ${ }^{219}$. Szczyt jego działalności finansowej przypada na koniec lat 60. i pierwszą połowę lat 70. XVI w. Działalność społeczna Jana Niedźwiedzia w życiu gminy nie była tak aktywna, jak działalność gospodarcza. Był jednak notowany jako opiekun dzieci Agnieszki i Jana Karasiów (sukienników ${ }^{220}$ ) oraz poręczyciel długu szewca Lorincza ${ }^{221}$.

\section{JAN ORZESZEK}

W dekrecie malborskim wszyscy przywódcy, oprócz Jana Orzeszka, zostali wymienieni z informacją o wykonywanym zawodzie. Natomiast w zapisach ksiąg radzieckich Orzeszek występuje jako krawiec z Przedmieścia Halickiego ${ }^{222}$. Jan Orzeszek pochodził z miasta Waręż w województwie bełskim ${ }^{223}$. Nie był powiązany z przedstawicielami elity władzy Lwowa, miał zaś powiązania z wybitnymi i znanymi ludźmi mieszkającymi na przedmieściach Lwowa, zwłaszcza Halickim. Po przybyciu do Lwowa Orzeszek osiedlił się na tym przedmieściu. Pierwsza żona, Anna ${ }^{224}$, była córką Stanisława Krakowianina, podwójciego Przedmieścia Halickiego ${ }^{225}$. W 1568 r. Orzeszek uzyskał obywatelstwo miejskie ${ }^{226}$, w roku następnym ożenił się z Elżbietą 227 , córką Jana i Anny Dunajowskich ${ }^{228}$. Jej

\footnotetext{
${ }^{216}$ Położony między Alberta Stelmacha i Chwedoreka (CDIAUL, spr. 13, s. 955 [1564 r.]; CDIAUL, spr. 14, s. 296 [1566 r.]).

${ }^{217}$ Położony między Dawida Rusina i Tuchowej (CDIAUL, spr. 13, s. 928 [1563 r.]).

218 Położony między Fraczkowa Strachowskim domem i domem Stanisława Garbarza (CDIAUL, spr. 14, s. 175 [1566 r.]).

${ }^{219}$ CDIAUL, spr. 14, s. 257 (1566 r.), 763, 944 (1567 r.), 1149 (1568 r.); CDIAUL, spr. 15, s. 484, 668 (1571 r.), 968 (1572 r.), 1565 (1573 r.); CDIAUL, spr. 16, s. $472-473$ (1573 r.), 936 (1576 r.), 1616 (1577 r.).

${ }^{220}$ CDIAUL, spr. 14, s. 349, 858 (1566 r.).

${ }^{221}$ CDIAUL, spr. 14, s. 950 (1568 r.).

${ }^{222}$ CDIAUL, spr. 19, s. 813-814 (1587 r.); CDIAUL, spr. 383, s. 384 (1576 r.).

${ }^{223}$ Album civium Leopoliensium ..., nr 2728.

${ }^{224}$ Po śmierci Anny, jej krewni domagali się podziału majątku po niej (CDIAUL, f. 52, op. 2 , spr. 15 , s. 118, 205 [1570 r.]).

${ }^{225}$ CDIAUL, spr. 15, s. 2006 (1573 r.).

${ }^{226}$ Album civium Leopoliensium ..., nr 2728.

${ }^{227}$ Ossol. rkps nr 826, Regestrum nuptiarum ..., s. 53 (1569 r.).

${ }^{228}$ CDIAUL, f. 52, op. 2, spr. 15, s. 51, 115 (1570 r.), 515 (1571 r.), 1560 (1573 r.).
} 
brat, Piotr Dunajowski, krawiec, również brał udział w wystąpieniu mieszczan ${ }^{229}$ i w 1579 r. został wybrany do Kolegium „Czterdziestu Mężów” przez kupców. Pozostał członkiem tej instytucji do $1582 \mathrm{r}^{230}$

Mało wiemy o działalności Jana Orzeszka na terenie miasta. Nie mamy informacji o jego działalności społecznej jako opiekuna czy plenipotenta. Nie odnotowano też jego aktywności finansowej. Są tylko wzmianki o transakcjach między nim a Wawrzyńcem Krakowianinem ${ }^{231}$, Piotrem Dunajowskim ${ }^{232}$ i Simonem Sterną $^{233}$ oraz Mikołajem Orzeszkiem z Warszawy (chyba krewnym) ${ }^{234}$, a także szlachcicem Janem Wierzbickim ${ }^{235}$. Taka mała aktywność w życiu publicznym miasta była prawdopodobnie spowodowana tym, że był on bardziej związany z Przedmieściem Halickim, na którym mieszkał i pracował. Nie łączył swoich zajęć z handlem czy działalnością finansową w mieście. Natomiast wiadomo, że w trakcie konfliktu Jan Orzeszek zabiegał o prawo przedmieszczan do produkcji trunków. Posiadamy informacje o królewskich dekretach przyznających Orzeszkowi „listy bezpieczeństwa” oraz nadających mu prawo do szynkowania trunków w jego domu na Przedmieściu Halickim ${ }^{236}$.

Jako człowiek nowy w środowisku lwowskim, nie posiadał dużego majątku nieruchomego. Wszystkie nieruchomości, które miał, uzyskał drogą ożenków w posagu swoich żon, których miał trzy. Po śmierci pierwszej żony, Anny Krakowianki w 1570 r., pozostała mu część domu na Przedmieściu Halickim²37; w tym roku wykupił również części innych spadkobierców swego teścia, Stanisława Krakowianina ${ }^{238}$. Dom ten wynajmowała u niego Zofia Rybiczanka z czynszem rocznym 100 fl. ${ }^{239}$ Po zawarciu małżeństwa z Elżbietą nastąpiło powiększenie jego majątku. Wszedł w posiadanie części kamienicy „Dunajowskiej” na ul. Krakowskiej ${ }^{240}$ oraz części browaru na tej ulicy ${ }^{241}$. Za jakiś czas, wraz z bratem żony Anny - Piotrem Dunajowskim, wykupił części innych spadkobierców ${ }^{242}$. Po

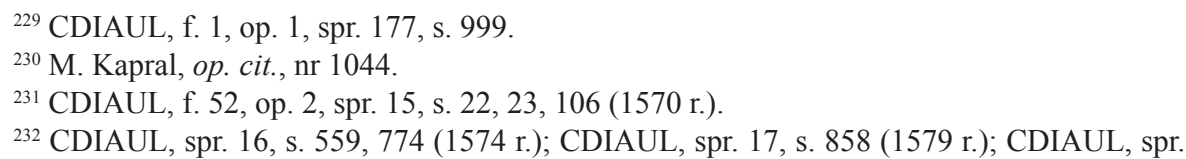
382, s. 83 (1574 r.).

${ }^{233}$ CDIAUL, spr. 382, s. 42 (1574 r.).

${ }^{234}$ CDIAUL, spr. 383, s. 574 (1586 r.).

${ }^{235}$ CDIAUL, spr. 382, s. 64 (1574 r.).

${ }^{236}$ CDIAUL, f. 9, op. 1, spr. 336, s. 1098-1099 (1577 r.); AGZ, nr 1816 (regestr).

${ }^{237}$ Dom był położony na Przedmieściu Halickim za Kościołem Bernardynów, koło domu Kinostowskiego i bocznym (CDIAUL, f. 52, op. 2, spr. 15, s. 118 [1570 r.]).

${ }^{238}$ CDIAUL, spr. 15, s. 205, 206 (1570 r.).

${ }^{239}$ CDIAUL, spr. 15, s. 1129 (1573 r.).

240 Kamienica była rozmieszczona na ulicy Krakowskiej między kamienicami Jerzego Juraszkowskiego i Alberta Szewca (CDIAUL, spr. 15, s. 44 [1570 r.]).

${ }^{241}$ CDIAUL, spr. 15, s. 515 (1571 r.).

${ }^{242}$ W 1573 r. swoją część im sprzedała Zofia, wdowa po Albercie Ślusarzu, siostra Piotra 
śmierci powinowatego Piotra, Jan Orzeszek odkupił od spadkobierców jego część kamienicy ${ }^{243}$. Także po trzecim małżeństwie z Anną Zalasowską uzyskał Orzeszek część domu jej rodziny na ul. Krakowskiej ${ }^{244}$.

Z powyższych rozważań wynika, że przywódcy opozycji mieszczańskiej w czasie tumultu przeciwko radzie miejskiej w latach 1576-1577 byli ludźmi dość bogatymi, posiadającymi liczne nieruchomości w mieście. Zarazem nie posiadali oni władzy w mieście. Warto wspomnieć, że większość z nich w okresie wydarzeń miała około 30 lat. Jedynie Jan Zaidlicz miał już około 50 lat. Mimo młodego wieku cieszyli się uznaniem wśród mieszczan, o czym świadczy ich częsta obecność przy różnych ugodach zawieranych przez obywateli miasta. Mieszczanie mieli do nich zaufanie, skoro obok urzędników miejskich (wójta i ławników) prosili ich na rozjemców, pełnomocników czy poręczycieli. Byli to także ludzie dobrze zapoznani z nadużyciami rajców. $Z$ tego powodu mogli formułować konkretne zarzuty oraz skutecznie bronić interesów pospólstwa w trakcie procesów przed sądem grodzkim i królewskim. Zapewne przywódcy opozycji mieli ambicje wejścia do lwowskiej elity władzy, wynikające z tradycji rodzinnych, gdyż przodkowie części z nich byli jej członkami. Jednak ówczesna elita władzy na to nie pozwalała, blokując im awanse. Można przypuszczać, że głównym powodem zaangażowania tych ludzi w organizację ruchu mieszczan przeciw radzie było pragnienie rozpoczęcia kariery urzędniczej. Jeśli przyjrzeć się dalszym losom przywódców rozruchów, można zauważyć, że Jan Zaidlicz po konflikcie zrezygnował z obywatelstwa miejskiego i opuścił Lwów, a jego interesy w mieście w latach 80 . XVI w. reprezentowała żona, Katarzyna ${ }^{245}$. Wszedł on w szeregi szlachty, co było wówczas celem wielu bogatych mieszczan. Z kolei najbardziej zyskali na następstwach rozruchów dwaj przywódcy: Jan Ganszorn oraz Jakub Soszka, którzy byli członkami cechu kuśnierzy. Zostali oni bowiem wybrani do składu kolegium „40 mężów” - instytucji, która miała reprezentować w okresie następnym interesy kupców i rzemieślników Lwowa oraz tworzyć tzw. III ordynek ${ }^{246}$.

i Anny (CDIAUL, spr. 15, s. 1560 [1573 r.]); w 1578 r. swoją część sprzedał im brat, Bartłomiej Dunajowski (CDIAUL, spr. 17, s. 756, 757; CDIAUL, spr. 18, s. 28-30 [1580 r.]).

${ }^{243}$ CDIAUL, spr. 19 , s. 242-248 (1585 r.).

${ }^{244}$ Dom był rozmieszczony na ul. Krakowskiej, między domami Iwaszkowskim i Kiernoszowskim (CDIAUL, spr.18, s. 1169 [1584 r.]; CDIAUL, spr. 19, s. 1181 [1588 r.]; CDIAUL, spr. 20, s. $710[1589$ r.]).

${ }^{245}$ CDIAUL, spr. 702, s. 44, 134, 153, 170, 192, 212.

${ }^{246}$ J. Ganszon był członkiem Quadragintawiratu w latach 1579-1589 (zob. M. Kapral, op. cit., s. 383), zaś J. Soszka - w latach 1579-1588 (ibidem, s. 409). 
Rzemieślnicy aktywnie domagali się wówczas dostępu do władz miejskich, jak miało to miejsce przed 1519 r., kiedy starsi cechowi brali udział w wyborach władz miejskich. W trakcie zamykania się grupy rządzącej, z której powoływano radę miejską jako organ władzy, cechy straciły ten wpływ. Dlatego w rozruchach z lat 1576-1577 pragnęli ponownie uzyskać dostęp do udziału w elekcji władz miejskich. Procedura wyborów, według której cechy brały pośredni udział w elekcji dwóch rajców, była rozpowszechniona w wielu innych miastach, np. w Lublinie, Sandomierzu, Przemyślu, Poznaniu i Kaliszu ${ }^{247}$. Procedura wyborów władz miejskich w Kaliszu, znana przecież we Lwowie, polegała na tym, że cechmistrzowie wybierali 12 kandydatów na rajców, a starosta generalny wielkopolski z tych 12 kandydatów wybierał sześciu rajców urzędujących, z których jednego powoływał na burmistrza. Prawdopodobnie przedstawiciele cechów lwowskich domagali się wprowadzenia podobnej procedury wyborów w swoim mieście i dlatego pozyskali opis procedury wyborczej z Kalisza, który zachował się do dzisiaj w archiwum lwowskim ${ }^{248}$. Wydaje się, że omówione powyżej argumenty dotyczące roli rzemiosła wzmacniają hipotezę R. Szczygła o tym, że dokument z Kalisza został dostarczony do Lwowa w latach 70. XVI w. Pewne elementy procedury wyborczej Kalisza odpowiadały bowiem części opozycji we Lwowie, dlatego właśnie rzemieślnicy, którzy byli najbardziej zainteresowani przyjęciem takiego sposobu wyborów i zarazem odgrywali aktywną rolę w konflikcie, mogli zainteresować się tą procedurą wyborczą i sprowadzić ją do swego miasta ${ }^{249}$.

Podsumowując, warto zauważyć, że w czasie wystąpienia społecznego mieszczaństwa lwowskiego przeciwko radzie miejskiej z lat 1576-1577 ważną rolę odegrali przedstawiciele organizacji zawodowych. To właśnie dzięki nim wystąpienie nie było tylko spontaniczną akcją społecznego sprzeciwu, lecz przekształciło się w świadomie przygotowaną akcję pospólstwa. Stanowili oni szerokie zaplecze dla osób, które zajmowały się przygotowaniem wystąpienia oraz spisywaniem postulatów różnych części opozycji. W trakcie rozpraw sądowych opozycję reprezentowało sześć osób (Jan Zaidlicz, Jan Ganszorn, Jan Szulczik, Jan Niedźwiedź, Jan Orzeszek i Jakub Soszka). Należeli oni do grupy najbogatszych członków opozycji i zarazem nie mieli władzy w mieście. Jako dobrze znający nadużycia rajców, mogli formułować trafne zarzuty oraz skutecznie bronić interesów pospólstwa w trakcie procesów przed sądem grodzkim i królewskim. Można też stwierdzić, że celem nadrzędnym opozycji pospólstwa

${ }^{247}$ J. Ptaśnik, Miasta i mieszczaństwo w dawnej Polsce, Warszawa 1949, s. 67.

${ }^{248}$ R. Szczygiel, Zainteresowanie kaliska procedura wyboru rady miejskiej we Lwowie $w$ drugiej połowie XVI wieku, [w:] In tempore belli et pacis. Ludzie - miejsca-przedmioty. Ksiega pamiatkowa dedykowana prof. dr. hab. Janowi Szymczakowi w 65-lecie urodzin i 40-lecie pracy naukowo-dydaktycznej, red. T. Grabarczyk, A. Kowalska-Pietrzak, T. Nowak, Warszawa 2011, s. 471.

${ }^{249}$ Ibidem, s. 472-473. 
było rozszerzenie społecznego kręgu władzy w mieście oraz uzyskanie większego wpływu obywateli na funkcjonowanie gminy miejskiej, co zawsze interesowało członków pospólstwa miejskiego. $Z$ tych też powodów działalność opozycji przeciwko rządom rady miejskiej interesowała szerokie rzesze społeczności miejskiej Lwowa.

\section{BIBLIOGRAFIA}

Akta grodzkie i ziemskie z czasów Rzeczypospolitej Polskiej z archiwum bernardyńskiego we Lwowie, wydał X. Liske [et al.], t. 10, Lwów 1884.

Album civium Antiquae Varsoviae. Księga przyjęć do prawa miejskiego Starej Warszawy 15061586, oprac. A. Bartoszewicz, Warszawa 2000.

Album civium Leopoliensium. Rejestry przyjęć do prawa miejskiego we Lwowie 1388-1783, wyd. A. Janeczek, t. 1-2, Poznań - Warszawa 2005.

Centralnyj Derżawnyj Istorycznyj Archiw Ukrainy u Lwowi.

Hul O., Konflikt między pospólstwem a władzami miasta Lwowa w latach 1576-1577. Przebieg wydarzeń i zasięg społeczny, [w:] Emocje w życiu mieszkańców miast na przestrzeni dziejów. Zbiór studiów, red. A. Buczyło, J. Możdżeń, A. Mutrynowska, Toruń 2015.

Kapral M., Urzędnicy miasta Lwowa w XIII-XVIII wieku, [w:] Spisy urzędników miejskich z obszaru dawnej Rzeczypospolitej, Ślaska i Pomorza Zachodniego, t. 7: Ziemie Ruskie, z. 1, Lwów Torun 2008.

Księgi przyjęć do prawa miejskiego w Krakowie 1573-1611. Libri iuris civilis Cracoviensis 15731611, wyd. A. Kiełbicka, Z. Wojas, Kraków 1994.

Łoziński W., Patrycjat i mieszczaństwo lwowskie w XVI-XVII wiekach, Lwów 1890.

Привілеї міста Львова XIV-XVIII cm., зб. док., упоряд. М. Капраль, Львів 1998.

Ptaśnik J., Miasta i mieszczaństwo w dawnej Polsce, Warszawa 1949.

Ptaśnik J., Walki o demokratyzację Lwowa od XVI do XVIII wieku, „Kwartalnik Historyczny” 1924, R. 38.

Ptaśnik J., Wiadomości o trzech lwowskich padewczykach. Odbitka z „Prac Polonistycznych” ofiarowanych prof. Janowi Łosiowi, Warszawa 1927.

Соиіальна боротьба в місті Львові в XVI-XVIII cm., зб. док, під ред. Я. Кіся, Львів 1961.

Szczygieł R., Konflikty społeczne w miastach Królestwa Polskiego w XV i XVI wieku, związane z dostępem do władz miejskich, http://history.org.ua/JournALL/socium/7/4.pdf [dostęp: 10.02.2017].

Szczygieł R., Zainteresowanie kaliska procedura wyboru rady miejskiej we Lwowie w drugiej połowie XVI wieku, [w:] In tempore belli et pacis. Ludzie - miejsca - przedmioty. Ksiega pamiatkowa dedykowana prof. dr. hab. Janowi Szymczakowi w 65-lecie urodzin i 40-lecie pracy naukowo-dydaktycznej, red. T. Grabarczyk, A. Kowalska-Pietrzak, T. Nowak, Warszawa 2011.

Urzędnicy miejscy Krakowa, cz. 2: 1500-1794, oprac. Z. Noga, Kraków 2008.

Заяць О., Громадяни Львова XIV-XVIII ст.: правовий статус, склад, походження, Київ Львів 2012. 


\section{SUMMARY}

In the second half of the seventies of the $16^{\text {th }}$ century Lviv became the arena of the civil protests against the authority of the Town Council. The main causes of the conflict were the internal situation of the town and the functioning of its municipalities. Counsellors did not try to make conversations with representatives of the opposition, offended them, and even threatened with punishment. It was the reason for the populace to address a complaint to the king. Several people (Jan Zaidlicz, Jakub Soszka, Jan Szulczik, Jan Ganszorn, Jan Niedźwiedź, Jan Orzeszek), who represented the community of the Lviv townsfolk at sessions of the Court in Lviv and at the Royal Court, took the lead of the townsfolk opposition during the course of events. They were rather rich but, at the same time, didn't have the authority in the town. Apparently, the main reason for these people engaged themselves in the organization of the townsfolk movement against the authorities was the desire to join the power elite, or to eliminate barriers between the elite and the townsfolk. This movement got the support among many groups of Lviv inhabitants.

Keywords: Lviv; civil protests; conflict; populace; Town Council; opposition 